\title{
ABO Blood Groups and Cirrhosis of the Liver
}

\section{A. J. ZUCKERMAN}

\section{From the London School of Hygiene and Tropical Medicine, and in collaboration with the Royal Free Hospital}

In a recent study, Zuckerman and McDonald (1963) found a significant excess of blood group A and a deficiency of group $\mathrm{O}$ in patients with acute viral hepatitis. It seemed, therefore, worth while to study the blood group distribution in patients with cirrhosis of the liver.

\section{Subjects and Methods}

The complete medical records of 347 patients with cirrhosis attending Professor Sheila Sherlock at the Royal Free Hospital, London, were examined. The diagnosis of cirrhosis was confirmed in each case by liver biopsy and/or necropsy. Of the 347 patients, 21 had been born outside the British Isles, leaving 326 patients for analysis. The distribution of blood groups to serve as a control was based on figures kindly provided by Dr. A. C. Kopéc of the Blood Group Centre of the Royal Anthropological Society. It has been shown that the regional distribution of blood groups in the British Isles differs significantly, and the country may be divided into 33 areas (A. C. Kopéc, 1964, personal communication). The results from 2 ro patients with cirrhosis, which includes types commonly referred to as

Received August 24, 1965. portal, post-necrotic, post-hepatitic cirrhosis, but excluding the types named primary biliary cirrhosis, juvenile cirrhosis, and those associated with a clear history of alcoholism, were compared with the controls in four regional groups, according to their place of residence. The exact geographical designations of these areas which include the London region, South East, South West England, and the Midlands are available on request.

\section{Results}

The distribution of the $\mathrm{ABO}$ blood groups in the 210 patients studied is shown in the Table. The statistical significance of the difference between the distribution of blood groups $A$ and $O$ for the patients and the controls was tested by the method of Woolf (1955). The differences were not significant $(p=>0 \cdot 2)$. The $\chi^{2}$ value for heterogeneity was also not significant $(p=>0 \cdot I)$.

\section{Discussion}

Billington (1956), in Australia, analysed the records of I I patients with cirrhosis and bleeding oesophageal varices. There was a marked excess of group A. Wewalka (1960) reported similar findings

TABLE

INCIDENCE OF BLOOD GROUPS A AND O IN PATIENTS WITH CIRRHOSIS BY GEOGRAPHICAL REGION

\begin{tabular}{|c|c|c|c|c|c|c|}
\hline \multirow{2}{*}{ Region } & \multicolumn{2}{|c|}{ No. in Disease Series* } & \multicolumn{2}{|c|}{ Controls } & \multirow{2}{*}{$\begin{array}{c}\text { Relative Incidence } \\
\mathrm{A}: \mathbf{O}\end{array}$} & \multirow{2}{*}{$x^{2}$} \\
\hline & Group O & Group A & Group O & Group A & & \\
\hline $\begin{array}{l}23 \\
29 \\
30 \\
31\end{array}$ & $\begin{array}{r}15 \\
8 \\
34 \\
25\end{array}$ & $\begin{array}{l}14 \\
12 \\
43 \\
31\end{array}$ & $\begin{array}{r}27934 \\
7743 \\
9379 \\
21360\end{array}$ & $\begin{array}{r}25763 \\
7114 \\
8072 \\
21751\end{array}$ & $\begin{array}{l}1 \cdot 101 \\
1 \cdot 632 \\
1 \cdot 469 \\
1 \cdot 217\end{array}$ & $\begin{array}{l}0.067 \\
2.497 \\
2.796 \\
0.554\end{array}$ \\
\hline TOTAL & 82 & 100 & & & $\begin{array}{c}\text { Mean relative } \\
\text { incidence }=\mathrm{I} \cdot 355\end{array}$ & 5.914 \\
\hline \multirow{2}{*}{$x^{2}$} & \multicolumn{4}{|c|}{$\begin{array}{l}\text { Difference from unity } \\
\text { D. of F. = I }\end{array}$} & \multicolumn{2}{|c|}{$(p=>0.937$} \\
\hline & \multicolumn{2}{|c|}{$\begin{array}{l}\text { Heterogeneity } \\
\text { D. of } F .=3\end{array}$} & & & \multicolumn{2}{|c|}{$\left(p=>\begin{array}{r}4.977 \\
0.1\end{array}\right)$} \\
\hline
\end{tabular}

* 28 patients belonged to groups $B$ and $A B$ and are excluded. 
in portal cirrhosis from Austria. It is possible to combine our results with those of Billington and Wewalka, using Woolf's method, but the patients as well as the controls are not strictly comparable. Although there is an excess of group A in all four regions, we were unable to demonstrate significant differences from the expected distribution of blood groups calculated from the control series, but the numbers of patients are rather small. Our previous observations provided evidence for an association of group A with acute hepatitis, but the proportion of patients with hepatitis who may proceed later to cirrhosis is not great, probably in the region of $1-5 \%$. Furthermore, our study in viral hepatitis was carried out in airmen whose place of birth was known, and comparison was made with Royal Air Force recruits whose place of birth was also recorded. It is quite possible that in the present investigation the comparison of patients with the controls is not sufficiently accurate to bring out any significant differences that may occur.

\section{Summary}

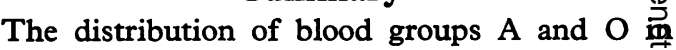
182 patients with cirrhosis attending a London hospital was compared with a sample of registered blood donors in four regions of the British Isles. There were no significant differences from the expected proportions calculated from the contregl figures.

\section{REFERENCES}

Billington, B. P. (1956). A note on the distribution of ABO blogs groups in bronchiectasis and portal cirrhosis. Aust. Ann. Med.e

5ewalka, F. (1960). Die Blutgruppen bei Lebercirrhosen. Blut, 261 .

Woolf, B. (1955). On estimating the relation between blood groư and disease. Ann. hum. Genet., 19, 251.

Zuckerman, A. J., and McDonald, J. C. (1963). ABO blood group and acute hepatitis. Brit. med. $\mathcal{F} ., 2,537$. 